\title{
Hygienic farming system improved pig-rearers livelihood status in south-west region of Bangladesh
}

\begin{abstract}
The traditional pig-rearers are not concerned about the hygienic pig farming system in Bangladesh. This participatory research work was aimed to establish initial guidelines for hygienic pig producers in the production of piglets and high quality pork considering that traditional systems with access to out-door area are going to be the most unhygienic systems with low profitability. Therefore, one demonstration (demo) and ten homestead trial farms were established with the varieties available in South-west region of Bangladesh. In comparative study related to growth performance and birth of piglets, we placed one boar and one sow of four varieties traditional Local Black, Dolkomol, Whitish and Banibunu in demo and in trial farms, also placed one boar and one sow of Black and Dolkomol varieties. We supplied them $01 \mathrm{~kg}$ balanced concentrate feed and $02 \mathrm{~kg}$ roughages to each animal daily. In demo, growth performance (body weight) of Black variety was highly gained $(61.3$ and $64.3 \mathrm{~kg}$ ) compared with Dolkomol (55.7 and 57.5kg), Whitish (58.0 and 62.0kg) and Banibunu (47.8 and $43.6 \mathrm{~kg}$ ) in both of boar and sow, respectively. Further, the result shows that Black variety was higher consumable pig that fed in full amount. But Dolkomol and Whitish were preferred concentrate feed than roughage and Banibunu were consumed less amount of both type of feeds which we formulated in this study. White variety shown higher reproductive performance compared to Black and Dolkomol. Whitish sow gave birth of six healthy piglets, Dolkomol four and Local Black three piglets. The disease occurrence rate was observed in lower rate in Local Black variety compared to other varieties. In trial farms, we also found similar pattern of results. Therefore, these results may influence to the development of economically profitable hygienic farming systems for production of high quality pork and piglets in Bangladesh.
\end{abstract}

Keywords: pig, hygienic farming system, local variety, Bangladesh, pork
Volume 2 Issue 4 - 2017

\author{
AKM Mostafa Anower, 'Munir Ahmed, ${ }^{2}$ M \\ Mujibur Rahman, ${ }^{3}$ Abul Hasan, ${ }^{3}$ Muhammad \\ Ashraful Islam, ${ }^{2}$ Lutfor Rahman ${ }^{4}$ \\ 'Department of Microbiology and Public Health, Patuakhali \\ Science and Technology University, Bangladesh \\ ${ }^{2}$ Blue Gold Program, Bangladesh Water Development Board, \\ Bangladesh \\ ${ }^{3}$ Nice Foundation, Bangladesh \\ ${ }^{4}$ Department of Livestock Services, Bangladesh
}

\begin{abstract}
Correspondence: AKM Mostafa Anower, Department of microbiology and public health, patuakhali science and technology university, Barisal, Bangladesh, Email anower@pstu.ac.bd
\end{abstract}

Received: April 30, 2017| Published: October 18, 2017
Abbreviations: FSUP, food security for the ultra poor; $\mathrm{HH}$, house hold; FFS, farmers field school; FMD, foot and mouth disease; HS, hemorrhagic septicemia

\section{Introduction}

Pigs in Bangladesh have received little attention to date. Since a great majority of population is Muslim they do not keep pigs for religious reason. The cobbler, sweeper, Christian, nomadic people and tribal community people of the country raise non-descript domesticated pigs only. They keep pigs for their livelihood and also to maintain their social value. Though, out of 590 million pigs in the world, about $34 \%$ are raised in tropical countries. Due to the religious point of view and for the limited number of pork consumers, the pig population is not large compared to other ruminants and birds in Bangladesh. In addition, a pig enterprise contributes in many ways to improve the livelihood of poor and vulnerable small-scale farmers. Pork and other pig products provide for high value animal protein, the meat is easy to dress and has superior curing and storage qualities. Additional income is earned from the sale of animals and importantly from their products. This additional income can be used to invest in farm assets, pay for school fees and medical treatments. Pigs provide income for women, strengthening their role in families as well as in local communities. ${ }^{1}$

Furthermore, it is difficult to get the exact number of pigs in Bangladesh. But the pig population is increasing in the tribal areas. ${ }^{2}$ Due to the high number of piglet born, easy rearing with available natural resources, high disease resistance and low production cost, pig rearing is getting importance in the tribal regions to eliminate poverty. Such as in study areas, there are some tribal communities are rearing pigs by receiving asset grant from the FSUP (Food Security for the Ultra Poor) project funded by European Union. In this area, pigs are predominantly belongs to the native and indigenous dwarf type producing low quality pork. ${ }^{3}$ The pig rearing continues to be primitive scavenging in nature because they are raised by certain rural people who are educationally, economically and socially most backward (Figure 1). Therefore, it has a great value to identify brucellosis in pigs because of socioeconomic impacts of rural ultra poor people. Nearly all pigs in Bangladesh are indigenous type and are kept under nomadic or grazing condition though rising in confined and tethering form is not uncommon. They are characterized as the pig of typical Short-ear type found in the mountainous areas of Southeast Asia and China having straight face with erect ears. Coat colors showed a remarkable diversity. Especially the patterns of self-black and black with white belly were predominant. ${ }^{4}$ There is only one government pig farm in the Rangamati district of in Bangladesh. Wild relatives of indigenous pigs are reported to be seen in the forest areas (Rangamati and Hill Tracts) of the country. ${ }^{5}$

The Nice Foundation (National NGO of Bangladesh) focuses on the Kawra and pig rearing communities whom are treated as untouchable among the minority Hindu community. They are neglected because of their profession. They are used to rear/cultivate pigs, eat pork and trade those in and outside of the country. This community tookup pig-rearing as a profession, as pork has a large market among 
Hindus, Christians, foreigners in Dhaka and international hotels. Their major livelihood is pig-rearing which is not accepted by the majority Muslim community. Moreover, many pigs and piglets are dying of unknown diseases, as the Government has limited treatment facilities. In addition, there are limited diagnostic facilities in the regional and local livestock offices and even this community is not calling Veterinary Officers for treatment. Furthermore, there is no permission and recognized shops to sell pork in local market. Class and status gaps create discrimination, resulting in a loss of selfconfidence. Majority communities possess their lands illegally and control their resources. They have no opportunity to participate even in the lowest local government structure. The traditional pig rearing is unhygienic and not socially supportive. Considering the above situation a participatory action research has been taken up to identify the root causes, their socioeconomic livelihood pattern, access to government resources, marketing facilities of pork, treatment facilities of pigs, blending of indigenous knowledge with modern pig rearing technology and behavioral pattern of neighbors to ensure their livelihood security. The action research focuses on how hygienic pig farming system may influence to improve livelihood status of pig rearing community in south-west region of Bangladesh.

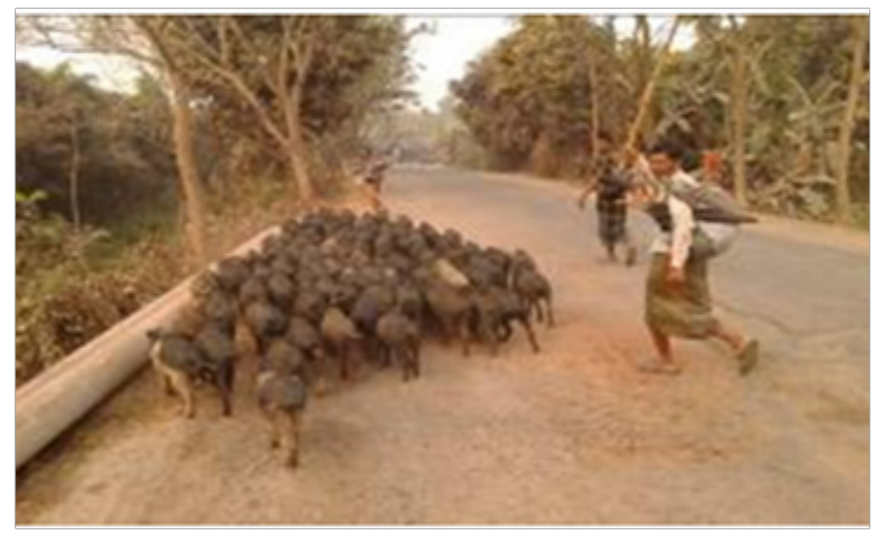

Figure I Traditional pig rearing in Bangladesh.

\section{Materials and methods}

\section{Selection of study area}

The study area was selected at Polder no. 30 under Batiaghata Upazilla of Khulna district (South-western region of Bangladesh). This polder is densely populated by lower caste Hindu who used to rear, culture and marketed the pigs. The study was conducted within water management group members who have pig rearing experience and living in different villages. Most of the ethnic groups are farmers that keep a good number of pigs, small ruminants and poultry in addition to cropping. Polder 30 is a humid area and is predominantly a Hindu dominated area where pig production and consumption is not prohibited. The location was purposively chosen for the study because majority of the farmers in the study areas are involved in pig production. The area is also known as local open pig markets in the area. A total of 200 households involved in pig rearing were selected from this area. The study was conducted in August 2015 to June 2016.

\section{Benchmark survey}

Before collection of data, a baseline questionnaire was prepared in accordance with objectives of the study. Later on, the questionnaire was validated against field condition. Before data collection, various households in different villages were visited. Finally, 200 pig owners from different sites were selected randomly and interviewed. Data related to housing, feeding, breeding, marketing, disease prevalence and major constraints of pig production were collected, compiled and analyzed. Descriptive statistics such as percentages, means scores and frequency tables were used in the analysis of the data generated.

\section{Establishment of pig demonstration (demo) and homestead farming-trial farms}

In demo farm, we placed one boar and one sow of four varieties of pigs-Local traditional black, Dolkomol, Whitish and Banibunu. Beside this, we tested the household (HH) base farming and $10 \mathrm{HHs}$ were selected and provided one boar and one sow of same variety to each. In this study, we tested $08 \mathrm{HHs}$ with Black and 02HHs with Dolkomol varieties. We supplied them concentrate and roughage feed and maintained sanitation, wastage disposal, vaccination and other health care regularly.

\section{Data analysis}

Data related to socio-economic status of pig-rearers and the management system and growth performances of demo and trial pig farms were collected, compiled and analyzed by using Microsoft excel 2007.

\section{Results and discussion}

\section{Socio-economic status of pig-rearers}

Sex and age characteristics of respondents: The result indicates that the majority of pig keepers in the sample were females (87\%) with small proportion of males (13\%). Women empowerment, their access and rights, social and family security and many other problems can be solved or can be partially solved from this point of view. The majority of the respondents were between ages 30 and 55 years $(73.5 \%)$ and $24 \%$ and $2.5 \%$ for $20-29$ and $55+$ year's age groups respectively (Table 1). The advantage of these types of age groups engaged in livestock activities will help in easy technology transfer and more flexible to new techniques and applications. ${ }^{6}$

Educational characteristics of respondents: The educational status of pig keepers in the study area is shown in Table 1. The majorities of pig keepers in the study area are literate people from read and write up to primary level $(23 \%)$, secondary or higher level $(75.5 \%)$ with few illiterate groups $(1.5 \%)$. These kinds of educational status may facilitate the implementation of more appropriate in pig rearing procedures.

Land holding: The study indicates that $20 \%$ of respondents owned no agro land while $64 \%$ have less than two acre of land for farming, which is not sufficient to live in a subsistence agricultural system in Bangladesh (Table 1). Further, among the respondents, $81 \%$ have only 1-50 decimal homestead lands and 9\% have no land at all which ultimately indicates the vulnerability of livelihood and economic opportunities and income for the participants and drive them engaging in other types of work (Table 1). In fact, most of the landless people of this area of Batiaghata rear pigs to support their livelihood.

Livestock and pig ownership status of respondents: It was evident that, farmers of Farmers Field School (FFS) of the study area reared $100 \%$ Black variety and in an average 2.66 number of pig reared per household. Among the Black variety, they had $74 \%$ of boar and $26 \%$ sow (Table 1). There was no found any other varieties for rearing in the study area. Pigs were gained on an average $60-70 \mathrm{~kg}$ body weight until selling. The farmers who are rearing sow got 4.5 
numbers of piglets per pregnancy of sow and mortality rate was $44 \%$. Piglet management is very critical to the farmers and they had no any training on pig rearing before FFS through this project. For this reason farmers are shown low interest in rearing sow instead of boar. Most of the respondents are also rearing other species of livestock like cattle, goat, sheep and poultry. In this study we found that they reared pigs as an additional income generation.

Table I Socio-economic status of the respondents engaged in pig rearing

\begin{tabular}{|c|c|c|}
\hline Variables & Categories & Percentage (\%) \\
\hline \multirow{3}{*}{ Sex } & Female & 87 \\
\hline & Male & 13 \\
\hline & $20-29$ years & 24 \\
\hline \multirow[t]{3}{*}{ Age } & $30-55$ years & 73.5 \\
\hline & $55+$ years & 2.5 \\
\hline & Primary & 23 \\
\hline \multirow[t]{3}{*}{ Education } & Secondary or higher & 75.5 \\
\hline & Illiterate & 1.5 \\
\hline & No agro land & 20 \\
\hline \multirow{3}{*}{ Land } & Farming land & 64 \\
\hline & No Homestead land & 81 \\
\hline & Homestead land & 9 \\
\hline \multirow{2}{*}{ Pig ownership Status } & Rearing Boar & 74 \\
\hline & Rearing Sow & 26 \\
\hline \multirow{3}{*}{$\begin{array}{l}\text { Experience of Pig } \\
\text { rearing }\end{array}$} & >I year & 52 \\
\hline & $\mathrm{I}-3$ years & 32.5 \\
\hline & $<3$ years & 15.5 \\
\hline \multirow{2}{*}{ Purpose of Pig rearing } & Marketing & 92 \\
\hline & Consumption & 8 \\
\hline \multirow{3}{*}{$\begin{array}{l}\text { Seasonal variation in pig } \\
\text { rearing }\end{array}$} & Spring & 52 \\
\hline & Spring and Summer & 31 \\
\hline & Around the year & 12 \\
\hline \multirow{5}{*}{ Housing } & Fencing & 61 \\
\hline & Closed shed & 10 \\
\hline & Roof only & 29 \\
\hline & Floor (Soil) & 88 \\
\hline & Floor (concrete) & 12 \\
\hline \multirow{4}{*}{ Feeding } & Rice polish & 7I \\
\hline & Grasses & 10 \\
\hline & Kitchen Garbage & 16 \\
\hline & Unconventional feeds & 3 \\
\hline \multirow{7}{*}{ Pig Health Management } & Consult Veterinarian & 3 \\
\hline & $\begin{array}{l}\text { Consult rural animal } \\
\text { health practitioner }\end{array}$ & 24 \\
\hline & $\begin{array}{l}\text { No access to veterinary } \\
\text { services }\end{array}$ & 73 \\
\hline & No idea about vaccination & 69 \\
\hline & No deworming & 84 \\
\hline & Never used disinfectant & 100 \\
\hline & No training on pig rearing & 100 \\
\hline
\end{tabular}

Experience and purpose of pig keeping: Pig keeping in Polder 30 area is introduced livestock production as most of respondents have experience of pig keeping from less than a year 52\%, 1-3 years 32.5\% and more than 3 years $15.5 \%$ (Table 1). This indicates that pig keeping is an emerging livestock production. All pig owners were interested to pig keeping is for marketing (92\%) and pork consumption (8\%). In addition, they assured that the purpose of pig keeping in the study area was for profit and extra income. The result of this assessment indicated that pig rearing would be an additional income source to the poor people of minority group. The majority of respondents are interested because of its less land requirement as first followed by less capital and prolificacy.

Seasonal variation in pig fattening and breeding: Our field facilitator asked farmers which season is preferable for pig fattening and breeding and about $52 \%$ farmers prefer to rear pigs at spring while about $31 \%$ prefers at both spring and summer. Near about $12 \%$ farmers prefers rearing pigs year the round and rest of 5\% preferred other seasons in scatterly (Table 1). They chose dry seasons because of empty of agricultural land and availability of piglets.

Pig housing: In the study area, farmers were made housing with just fencing $(61 \%)$ rather than closed shed $(10 \%)$ and with roof only $(29 \%)$ (Table 1). In backyard farm, no ideal measurement was followed. The roofs of the sheds were made of Goalpata (52\%), straw $(27.5 \%)$ and others like soil tiles, tin, etc. (21.5\%). Further, floor of the house was made of soil (88\%) and concrete (12\%) (Table 1). In this study area, few conscious farmers were reduced heat stress by spraying water; pigs were allowed to wallow in nearby clay area during summer. The piggery was sited to take full advantage of prevailing winds by keeping both sides open. In winter, pigs were protected from cold by using thick cloths and gunny bags.

Feeding system: There was no provision for balanced feed supplementation in family level farming. The pig owners used to supply daily rice polish (71\%), grasses (10\%), kitchen garbage (16\%) and $(3 \%)$ with some unconventional feeds like cauliflowers, arum and hilly grass to adult and piglets (Table 1). They never supplied vitaminmineral premix for their growth. In addition, they supplied food to the pigs $01(4 \%), 02(88 \%), 03(8 \%)$ times in a day. The amount of feed depends on the age and the reproductive state of the pig. It is recommended that concentrate feed should be supplied at morning and evening and roughage should be provided at noon. Pigs rely on both concentrate and roughage. Rice polish is their most common food, but they could benefit from having a concentrate feed which is a balanced diet containing carbohydrate, protein, fat, etc. Further, they grow faster with vitamins and minerals. Piglets have higher protein requirements than mature ones.

Pig health management: From the total of respondents only $3 \%$ consult veterinarian and $24 \%$ consult rural animal practitioner while the remaining $73 \%$ had no access to veterinary services (Table 1 ). Most of pig keepers do not have sufficient knowledge how to manage sick pigs. From the total of respondents cull their dead animals in a traditional way. Mortality of pig is a problem in the study area. From the total of respondents $(69 \%)$ had no idea about vaccination and (84\%) never used anthelmintics for deworming their pigs (Table 1). This may be due to their lack of knowledge and insufficient training on pig rearing system. From total respondents $100 \%$ had no training. For the first time they received training on pig rearing from this program.

Sanitation and waste management: Sanitation is important to keep the pig's disease-free as well as human health. A mechanism 
for easy cleaning and removal of waste is necessary for any type of pig housing. Housing in a barn and removal of manure daily are recommended to keep the floor dry to reduce odor. Proper ventilation is required to remove ammonia $\left(\mathrm{NH}_{3}\right)$, methane $\left(\mathrm{CH}^{4}\right)$ and hydrogen sulfide $\left(\mathrm{H}_{2} \mathrm{~S}\right)$ gases. ${ }^{6-8}$ In this study, most of farmers $(100 \%)$ were not using any kind of disinfectant and they have no waste management systems. As a result they are rearing pigs in unhygienic manner with low production. For sanitation of pig house disinfectant should be used that are active against a wide range of viruses, bacteria and fungi, safe to handle, active in the presence of dust or organic matter, has a long period of activity, non-irritant, non-staining, non-toxic, noncorrosive, colored, safe and effective when used in water systems and capable of use through pressure washers. ${ }^{9}$

Consumption and income generation through pig rearing: On an average $29.07 \mathrm{~kg}$ pork was consumed by the respondent's family members per year. Mostly they sold adult pigs (average $n=2$ ) per year at home $(87 \%)$ or at village market $(13 \%)$. Most of farmers did not sell piglets. In this study we only found one farmer who sells twenty five piglets per year. Although selling price of pigs depends on body weight and disease free condition, they sold an adult pig average 9,787 BDT and each piglet 2000 BDT. They have no idea or they do not care about profit margin from sell of pigs/piglets, because they are rearing pigs in traditional method.

Public health significance: The study tried to assess the public health status of the persons who are involved with pig farming. Pig farm manure contains a number of components of concern to human health, including heavy metals and pathogenic bacteria, and may emit volatile gases. Numerous studies have shown adverse physical and mental health effects on both pig farm workers as well as people in neighboring communities. ${ }^{10-12}$ Eye, nose, and throat irritation, headache, nausea, diarrhea, cough, chest tightness, palpitations, shortness of breath, stress, and drowsiness are some of the most frequently reported problems. People suffering from asthma or allergies complain that the odors exacerbate their existing illness. Another study conducted in the U.S. state of North Carolina reported a significantly higher incidence of mental health symptoms, including increased levels of tension, depression, anger, fatigue, and confusion, amongst residents living near pig production facilities, in comparison to a control group. ${ }^{13}$ In this study, we also asked the farmers ever they suffered from any diseases during pig rearing. Only few participants said that they suffered from several symptoms like nausea, abdominal pain, skin diseases, headache, coldness, etc. There are many Zoonotic diseases occurred which may transmit to human. Aside from disease, another critical problem faced by conventional pig farmers is pig waste. Seeing as hogs on average produce three times the amount of excrement as humans, the waste of these animals presents a significant dilemma.

Constraints of pig production: Bangladesh is a majority Muslim country. Pork is prohibited in Islam religion. Muslim peoples are not interested in pig farming. Pigs are omnivorous and voracious animal. They require more feed daily. For the rural pig owner, it is difficult to meet up their demands for feed. ${ }^{14}$ As a result, pigs are suffering from malnutrition. The major feedstuffs of pigs that available are of low quality, which do not meet their productive and reproductive performances..$^{15}$ The maximum pig population of the study area was indigenous type which has low productivity in comparison to exotic breed. Minimizing mortality of piglets is a constraint. Young piglets fail to suckle their mother and gradually become weak and finally die. The farm owners have limitations in the knowledge of vaccination.
Pigs in family level farming often face diseases like Foot and Mouth Disease (FMD), Hemorrhagic Septicemia (HS) and anthrax. They have no interaction with local veterinary hospital. As a result, they do not know the causes of disease and preventive measure. There is lack of bio-security particularly in family level farming. Pigs are always exposed to other livestock and migratory birds and affected by diseases. ${ }^{2}$ Drugs are quite expensive. Most of pig owners are not interested to treat their pigs. Pigs often die from poor husbandry practices. Due to religious restriction, there is no established pork marketing system which in general, hinders pork production. Mid level buyers are controlling the local market. Alleviating constraints to marketing, improving marketing and market information, and upgrading marketing infrastructures will potentially increase the welfare of smallholder producers and urban consumers. The government should also work on cultural and behavioral change of the people and also formulate an appropriate policy regarding pig production in the livestock production strategy.

Performance of pig demonstration farm: In order to establish a hygienic pig farming system to follow by the farmers the research team has established a demonstration (demo) farm. In demo farm, 4 varieties of Banibunu, Local traditional Black, Dolkomol and White, total 4 male and 4 female were placed in farm. In order to see the cost effectiveness, growth and income from the different varieties, we supplied those concentrated feed and green grasses. In addition, we measured sanitation, wastage disposal, vaccination and other health care regularly (Figure 2).

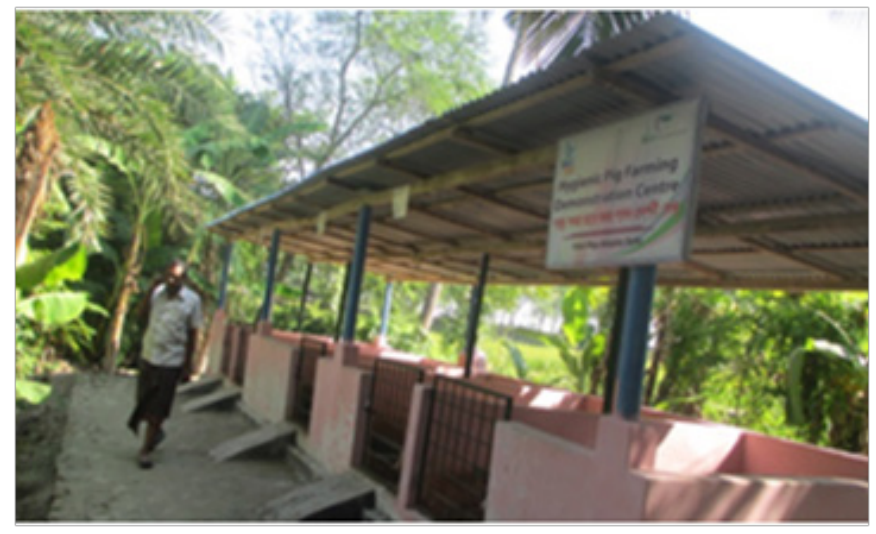

Figure 2 External view of pig demonstration farm.

Growth performance: The growth performance (body weight) of all varieties was recorded and results are shown in (Table 2). The result shows that within the research period Local Traditional Black (Black) variety was highly gained body weight (61.3 and $64.3 \mathrm{~kg})$ compared with Dolkomol (55.7 and 57.5kg), Whitish (58.0 and 62.0kg) and Banibunu (47.8 and $43.6 \mathrm{~kg}$ ) in both of boar and sow, respectively. Further, we found that sow were gained more compare to boar in Local, Dolkomol and Whitish varieties except Banibunu where boar was gained more compare to sow's. This is important that sow were gained high, because they took in a high amount of feed during pregnancy and weaning period. ${ }^{16}$ But the variety Banibunu was not pregnant during study period. In addition, it is noticed that Banibunu is rare variety in Bangladesh and we introduced them in demo farm in late stage.

Feed consumption rate: Feeding costs make up a large percentage of the total cost of pig production. Our research estimated to reduce feeding costs and to increase production. It is true that growth performance 
depends on daily feed intake and feed containing nutrients. ${ }^{17}$ The feed ingredients and supplements were used in all varieties are presented in (Table 2). The data presented on feed chart indicated that the rations so formulated which contained acceptable levels of nutrients. To minimize the cost, we adjusted balanced concentrate feed with roughages which are locally available. Therefore, we supplied them $01 \mathrm{~kg}$ balanced concentrate feed and $02 \mathrm{~kg}$ roughages to each animal daily (Figure 3). The concentrate feed was provided them two times in a day (half amount at morning and rest amount at evening) and the roughage was supplied at noon. The caretaker was recorded their intake of feed amount regularly. The daily feed intakes are presented in Table 2. The result shows that Black variety was higher consumable pig that fed in full amount. On the other hand, Dolkomol intake concentrate $(0.9$ and $1.0 \mathrm{~kg})$, White $(1.0$ and $1.0 \mathrm{~kg})$ and Banibunu $(0.8$ and $0.7 \mathrm{~kg})$ in both of boar and sow, respectively. Beside this, Dolkomol into krough age (1.8 and $2.0 \mathrm{~kg})$, Whitish (1.6 and $1.8 \mathrm{~kg})$ and Banibunu (1.8 and 1.6kg) in both of boar and sow, respectively. These results indicate that Dolkomol and Whitish are preferred concentrate feed than roughage and Banibunu were consumed less amount of both type of feeds which we formulated in this study.

Table 2 Performance of demonstration farm

\begin{tabular}{|c|c|c|c|c|c|c|c|c|c|}
\hline \multirow[b]{2}{*}{ Varieties } & \multirow[b]{2}{*}{ Sex } & \multicolumn{2}{|c|}{ At the Starting Period } & \multicolumn{2}{|c|}{ At the Ending Period } & \multirow{2}{*}{$\begin{array}{l}\text { Total Body } \\
\text { Weight } \\
\text { Gained (Kg) }\end{array}$} & \multicolumn{2}{|c|}{ Daily Feed Intake (Average) per Pig } & \multirow{2}{*}{$\begin{array}{l}\text { Birth of } \\
\text { Piglets } \\
\text { (No.) }\end{array}$} \\
\hline & & $\begin{array}{l}\text { Age } \\
\text { (wk) }\end{array}$ & $\begin{array}{l}\text { Body weight } \\
(\mathrm{Kg})\end{array}$ & $\begin{array}{l}\text { Age } \\
\text { (wk) }\end{array}$ & $\begin{array}{l}\text { Body weight } \\
\text { (Kg) }\end{array}$ & & $\begin{array}{l}\text { Concentrate } \\
(\mathbf{K g})\end{array}$ & $\begin{array}{l}\text { Roughage/ } \\
\text { Others (Kg) }\end{array}$ & \\
\hline \multirow{2}{*}{ Black } & Boar & 18 & 21.7 & 54 & 83 & 61.3 & I & 2 & \multirow{2}{*}{3} \\
\hline & Sow & 16 & 19.7 & 52 & 84 & 64.3 & 1 & 2 & \\
\hline \multirow{2}{*}{ Dolkomol } & Boar & 18 & 15.3 & 54 & 71 & 55.7 & 0.9 & 1.8 & \multirow{2}{*}{4} \\
\hline & Sow & 16 & 12.5 & 52 & 70 & 57.5 & I & 2 & \\
\hline \multirow{2}{*}{ Whitish } & Boar & 18 & 12 & 54 & 70 & 58 & I & 1.6 & \multirow{2}{*}{6} \\
\hline & Sow & 16 & 11 & 52 & 73 & 62 & I & 1.8 & \\
\hline \multirow{2}{*}{ Banibunu } & Boar & 8 & 7.2 & 44 & 55 & 47.8 & 0.8 & 1.8 & \multirow{2}{*}{-} \\
\hline & Sow & 8 & 6.4 & 44 & 50 & 43.6 & 0.7 & 1.6 & \\
\hline
\end{tabular}

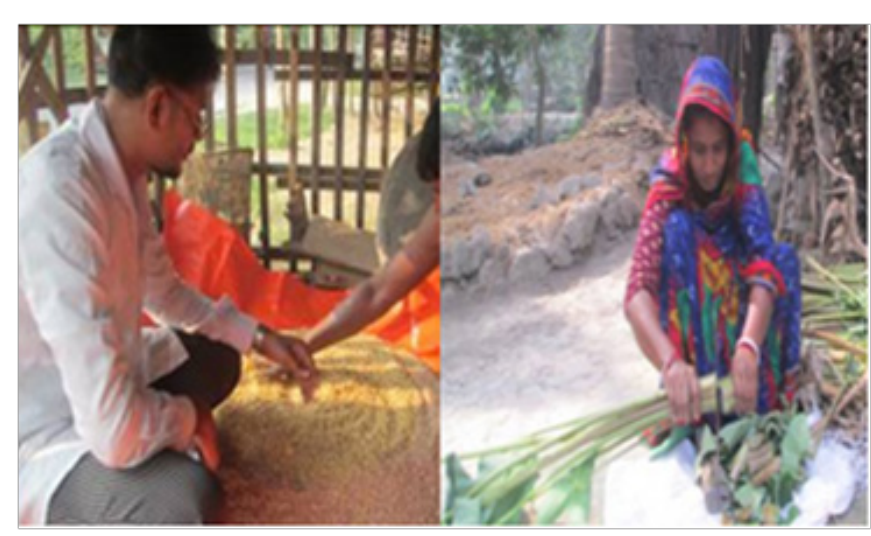

Figure 3 Processing of concentrate and roughages.

Reproductive performances: Reproductive performances of different varieties are shown in Table 2. Although growth and feed intake rate were low in White variety, but they shown higher reproductive performance in demo farm compare to Black and Dolkomol. Whitish sow gave birth of six healthy piglets, Dolkomol four and Local black three piglets. We were taken maximum care during birth of piglets. Unfortunately white sow gave birth at $1.25 \mathrm{am}$ at night and caretaker found them in the morning death. We did not get enough information on them to assess the real causes. Actually Whitish are more sensitive to our environment than other varieties including management system. In case of Dolkomol, two piglets were died within one month after birth and two piglets are alive. In case of Black, all of three piglets are alive till now. Therefore, higher survival rate of piglets was found in Black variety (Table 2).

Disease occurrence: The disease occurrence rate was observed in lower rate in demo farm due to proper management of sanitation and vaccinations were followed. Local variety was more resistant and did not find any diseases. There was not found any remarkable diseases during entire research period in demo farm except few diseases/ symptoms (Anorexia, fever, diarrhea and dermatitis) were observed in Dolkomol, Whitish \& Banibunu. ${ }^{18}$

Homestead farming-trial farms: The main achievement of the current research project is hygienic pig farming at household level is highly profitable against the investment and the piglet production is more profitable than the pig fattening (Table 3). In that case piglet management is more technical and need technical support to the pig farmers. Most of farmers are interested in fattening in this area. To increase the high interest in piglet production, we tested the household base farming and 10 households were selected and provided one boar and one sow of same variety to each. In this study, we tested $08 \mathrm{HHs}$ with Local and $02 \mathrm{HHs}$ with Dolkomol varieties.

Growth performance: The growth performance (body weight) of trial farms was recorded and results are shown in Table 3 . The result shows that Black variety gained more average body weight (50.5 and $55.6 \mathrm{~kg}$ ) compared to Dolkomol (45.5 and $49.5 \mathrm{~kg}$ ) in both of boar and sow, respectively. Here, we also found that body weight was higher in sow than boar in both of varieties. This result indicates that according to growth performance Local variety is the best at $\mathrm{HH}$ level pig farming.

Feed consumption rate: Traditional pig farmers do not care on balanced feed or amount of feeds of pigs. They mostly used to feed rice polish, boiled rice, kitchen garbage or arum. In this study, we provided our formulated concentrate feed to the farmers of trial farms. As demo farm, we also supplied $01 \mathrm{~kg}$ concentrate and $02 \mathrm{~kg}$ roughage feed to each animal. Most of them followed our instruction, but four farmers did not care. They mostly fed concentrate feed. They fed roughage at minimal level or not (Table 3 ). As a result we found their lower growth and specially lower reproductive performances. The result shows that Black variety was higher consumable pig that intake feed in full amount compare to Dolkomol. 
Table 3 Performance of homestead-trial farms

\begin{tabular}{|c|c|c|c|c|c|c|c|c|c|}
\hline \multirow[b]{2}{*}{ Varieties } & \multirow[b]{2}{*}{ Sex } & \multicolumn{2}{|c|}{ At the Starting Period } & \multicolumn{2}{|c|}{ At the Ending Period } & \multirow{2}{*}{$\begin{array}{l}\text { Total Body } \\
\text { Weight } \\
\text { Gained (Kg) }\end{array}$} & \multicolumn{2}{|c|}{ Daily Feed Intake(Average) per Pig } & \multirow{2}{*}{$\begin{array}{l}\text { Birth of } \\
\text { Piglets } \\
\text { (No.) }\end{array}$} \\
\hline & & $\begin{array}{l}\text { Age } \\
\text { (wk) }\end{array}$ & $\begin{array}{l}\text { Body weight } \\
\text { (Kg) }\end{array}$ & $\begin{array}{l}\text { Age } \\
\text { (wk) }\end{array}$ & $\begin{array}{l}\text { Body weight } \\
\text { (Kg) }\end{array}$ & & $\begin{array}{l}\text { Concentrate } \\
(\mathrm{Kg})\end{array}$ & $\begin{array}{l}\text { Roughage/ } \\
\text { Others (Kg) }\end{array}$ & \\
\hline \multirow{2}{*}{$\begin{array}{l}\text { Trial-I } \\
\text { (Black) }\end{array}$} & Boar & 18 & 22 & 53 & 80 & 58 & 1 & 2 & \multirow{2}{*}{7} \\
\hline & Sow & 17 & 21 & 52 & 82 & 61 & 1 & 2.2 & \\
\hline \multirow{2}{*}{$\begin{array}{l}\text { Trial-2 } \\
\text { (Black) }\end{array}$} & Boar & 18 & 22 & 45 & 71 & 49 & 2 & - & \multirow{2}{*}{-} \\
\hline & Sow & 17 & 21 & 44 & 78 & 57 & 2 & - & \\
\hline \multirow{2}{*}{$\begin{array}{l}\text { Trial-3 } \\
\text { (Black) }\end{array}$} & Boar & 14 & 23 & 44 & 67 & 44 & 1 & 2 & \multirow{2}{*}{6} \\
\hline & Sow & 14 & 21 & 44 & 70 & 49 & 1 & 2 & \\
\hline \multirow{2}{*}{$\begin{array}{l}\text { Trial-4 } \\
\text { (Black) }\end{array}$} & Boar & 14 & 18 & 45 & 68 & 50 & 2 & I & \multirow{2}{*}{5} \\
\hline & Sow & 14 & 18 & 45 & 73 & 55 & 2 & 1 & \\
\hline \multirow{2}{*}{$\begin{array}{l}\text { Trial-5 } \\
\text { (Black) }\end{array}$} & Boar & 14 & 18 & 44 & 65 & 47 & 1 & 2 & \multirow[b]{2}{*}{6} \\
\hline & Sow & 14 & 20 & 44 & 74 & 54 & 1 & 2 & \\
\hline \multirow{2}{*}{$\begin{array}{l}\text { Trial-6 } \\
\text { (Black) }\end{array}$} & Boar & 18 & 20 & 45 & 72 & 52 & 1 & 2 & \\
\hline & Sow & 18 & 19 & 45 & 76 & 57 & 1 & 2 & \multirow{2}{*}{4} \\
\hline \multirow{2}{*}{$\begin{array}{l}\text { Trial-7 } \\
\text { (Dolkomol) }\end{array}$} & Boar & 18 & 19 & 44 & 68 & 49 & 1.2 & I & \\
\hline & Sow & 22 & 25 & 48 & 75 & 50 & 1.2 & 1 & \multirow{2}{*}{-} \\
\hline \multirow{2}{*}{$\begin{array}{l}\text { Trial-8 } \\
\text { (Dolkomol) }\end{array}$} & Boar & 16 & 21 & 42 & 63 & 42 & 1.5 & 1 & \\
\hline & Sow & 14 & 17 & 40 & 66 & 49 & 1.5 & 1 & \multirow{2}{*}{6} \\
\hline \multirow{2}{*}{$\begin{array}{l}\text { Trial-9 } \\
\text { (Black) }\end{array}$} & Boar & 14 & 13 & 45 & 71 & 58 & 1.5 & 0.5 & \\
\hline & Sow & 14 & 14 & 45 & 78 & 64 & 1.5 & 0.5 & \multirow{2}{*}{6} \\
\hline \multirow{2}{*}{$\begin{array}{l}\text { Trial-10 } \\
\text { (Black) }\end{array}$} & Boar & 20 & 24 & 47 & 70 & 46 & 1 & 2 & \\
\hline & Sow & 18 & 26 & 45 & 74 & 48 & I & 2 & 5 \\
\hline
\end{tabular}

Reproductive performances: Reproductive performances of trial farms are shown in Table 3. Out of ten trial farms, piglets were born in eight farms, one (Trial-2) was shown three times heat but not conceived yet and in another one (Trial-7), boar was become sick then farmer replaced new boar in farm. Out of eight farms where we supplied Black variety, seven sows were pregnant. Again out of two farms where we supplied Dolkomol, one sow was pregnant, but another sow was not pregnant due to sick of boar. Among them, trial-1 (Black) shows higher reproductive performance by giving birth of seven piglets and lowers four piglets in trial-6 (Black). Average piglets production rate is 5.6 in each pregnancy. Feed consumption rate is closely related with reproductive performances. Two sows were not regnant due to imbalance feed supply and farmers careless to management. Therefore, we recommend that balance ration is essential to get piglets and Black variety is the best in piglet production at $\mathrm{HHs}$ level (Figure 4).

Disease occurrence: Most of trial farms were affected with few minor diseases/symptoms. But the farmers who were taken proper care, they benefited and got piglets. The farmers who were not maintained proper management of biosecurity, they did not get piglets yet.

Perceived social impact: One of our project concerns was to assess the social notions on pig rearing. The surrounding people are from same community and there have been no major obstacles of rearing pigs in the research area. Moreover, the farmers are motivated to farming in a hygienic system which was a predemand of the neighbors who are now happy and supportive to the piggery promotion. Nice Foundation research team collected data from the field and has asked 200 neighbors of pig farmers where all of them responded that if the pigs are rearing in a modern farming system then we do not have objections and we will welcome the organizations if they provide them with modern technology because it gives us nutrition and we love to eat pork at least once in a week. Our experiences in the Hindu and Muslim community found that the progressive Muslim leaders do not create any obstacles for rearing but their concern is to rear the pigs in isolated area where peoples' movement is comparatively less and the odor smell should not come out. Pig manures can be used for the purpose of bio-gas and organic fertilizer in agricultural field. We found that farmers who used pig waste in vegetable field, it gave good result alternative to chemical fertilizer. In other area in Aranghata, Dumuriaa Kawra family has bio-gas plant supported by BRAC. The farmers said, pigs are very friendly and manage themselves as one of the pet animal. The farmers rear those in two systems i.e; at household and open grazing system. The open grazing is at roadside, khasland, fallow land and off seasons in rice fields. During grazing pig droppings and other biological wastes are open which the land owners see it as organic fertilizer and allows in off time to graze. The household level pig droppings are instructed to manage through ring slab. The pig shed models were given to the community for managing the pig wastes. We found positive impact in the agricultural field. 


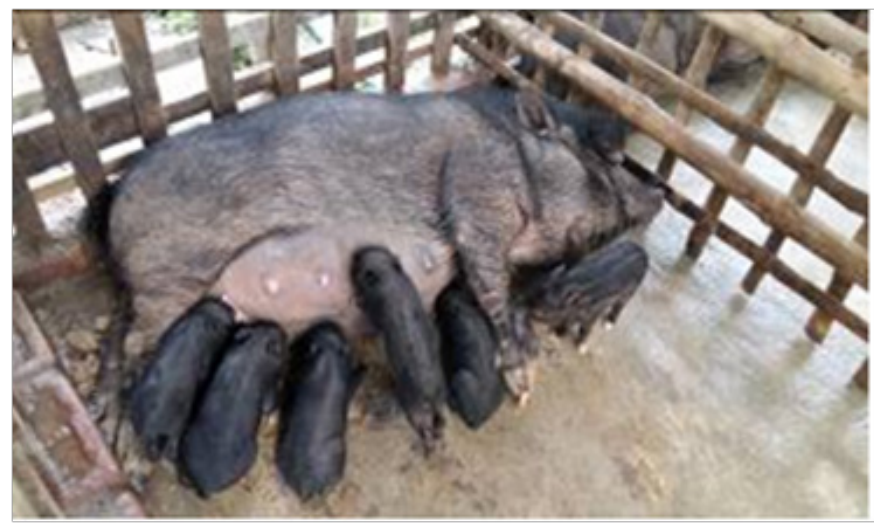

Figure 4 Sow with newborn piglets at trial farms.

Perceived environmental impact: In our benchmark survey report we found out of 200 respondents none has reported adverse effect of environment. Almost all 200 respondents said there are odor smell breezed that create nuisance in the society due to unhygienic farming system. At the end line we found $80 \%$ respondents said that odor smelling is reduced after installation of ring slab for managing pig wastes and 2-3 times sweeping of floors. $20 \%$ respondents said the situation improved slightly but need more hygienic attempt especially sweet water sources and drainage system in the farm.

\section{Conclusion}

This study revealed that the main purpose of pig production is to get additional income for the household. In addition, this study has highlighted a number of issues that are of major concern in the sustainability of local pig rearers, of importance is feeding, marketing and breeding. There is need to address these for full realization of the sectors potential. One of the possible ways that could reduce production costs is by farmers using locally available feedstuffs that would balance the nutrient requirements of the pig. Confinement of pigs would reduce the public health risks associated with pigs. Pig farming, with proper management, will provide pig farmers with an additional source of income. There is need to increase producer awareness on healthy husbandry practices through strengthened extension services. These coupled with additional research would promote healthy pork production and meet the local demand for the increasing pork consumption in Bangladesh. In order to disseminate the technology among the farmers trained person is essential in pig farming system. Combined feed formulation (concentrate feed with roughage) can minimize cost effectiveness and also promote more production. The traditional pig farmers are not concerned about the hygienic pig farming but after visiting our demo farm and trial shed they were encouraged to make their farms and sheds hygienic. The study pointed that the pig farming in the study area enabled producers to generate additional income which in turn helps in achieving food security self-employment for landless and unemployed people in the study area.

\section{Acknowledgements}

We are thankful to The Embassy of the Kingdom of The Netherlands (EKN) in Bangladesh and Blue Gold Program, Bangladesh for financing this work through 'Securing the livelihood through improvement of Kawra/pig-rearing community of Southwest Bangladesh' project, under Grant number: PU7 Innovation Fund.
We also thank to the pig rearing community, field facilitators of Nice Foundation, WMG and WMA members of Batiaghata, Bangladesh Water Development Board, Department of the Livestock Services and civil society members for accepting to participate in this study.

\section{Conflicts of interest}

Author declares there is no financial interest or any conflict of interest exists.

\section{References}

1. Klaas Dietze. Pigs for prosperity. Italy: Diversification Booklet; 2011. p. $1-67$.

2. Hossain ME, Chakma S, Khatun MM, et al. Production systems of swine in the rural areas of Rangamati and Khagrachari districts of Bangladesh Bangladesh Journal of Animal Science. 2011;40(1-2):28-33.

3. WFP. Food Security for the Ultra Poor. Bangladesh; 2012. p. 1-50.

4. Riedel S, Schiborra A, Huelsebusch C, et al. Opportunities and challenges for smallholder pig production systems in a mountainous region of Xishuangbanna, Yunnan Province, China. Trop Anim Health Prod. 2012;44(8):1971-1980

5. Ritchil CH, Faruque MO, Tabassum F, et al. The socio-economic status of pig rearers and the management system of native pigs in Bangladesh. Indian Journal of Animal Science. 2013;83(11):1226-1228.

6. King VL, Koketsu Y, Reeves D, et al. Management factors associated with swine breeding-herd productivity in USA. Prev Vet Med. 1998;35(4):255-264.

7. Lemke U, Kaufmann B, They LT, et al. Evaluation of Biological \& Economic Efficiency of Small Holder Pig Production Systems in North Vietnam. Trop Anim Health Prod. 2007;39(4):237-254.

8. Moore MJ. Basic requirements for intensive pig housing. Journal of Animal Science. 2002;78:234-267.

9. Smith JK. Swine Housing Requirement. Journal of Animal Science. 2005;74:924-940.

10. Cameron R. A Review of the Industrialization of Pig Production Worldwide with Particular Reference to the Asian Region. 2000.

11. Food and Agriculture Organization of the United Nations. The state of food and agriculture. Italy: Livestock in the balance; 2009. 27 p.

12. Food and Agriculture Organization of the United Nations. FAOSTAT Statistical Database. 2010.

13. Schiffman SS, Sattely MEA, Suggs MS, et al. The effect of environmental odors emanating from commercial swine operations on the mood of nearby residents. Brain Res Bull. 1995;37(4):369-375.

14. Johnson AK, Morrow JL, McGlone JJ. Behavior and performance of lactating sows and piglets reared indoors and outdoors. J Anim Sci. 2001;79(10):2571-2579.

15. Petrus NP, Mpofu I, Schneider BM, et al. The constraints and potentials of pig production among communal farmers in Etayi Constituency of Nambia. Livestock Research for Rural Development. 2011:23(7).

16. Prakash MG, Ravi A, Kumari BP, et al. Reproductive and Productive Performance of Crossbred Pigs. Indian Journal of Animal Science. 2008;78:1291-1297.

17. Walker R. Swine feeding. Journal Swine News. 2003;45:789-810.

18. Patr MK, Begum S, Deka BC. Problems and Prospects of Traditional Pig Farming for Tribal Livelihood in Nagaland. Indian Research Journal of Extension Education. 2014;14(4):6-11. 